\title{
Preterm Labor and the Associated Factors
}

\author{
Persalinan Preterm dan Faktor-faktor yang Terkait
}

\author{
Seno Adjie, Meily, Ranti P Permatasari \\ Department of Obstetrics and Gynecology \\ Faculty of Medicine, Universitas Indonesia/ \\ Dr. Cipto Mangunkusumo Hospital
}

Jakarta

\begin{abstract}
Objective: To determine the risk factors that affect preterm labor in Dr. Cipto Mangunkusumo Hospital.

Methods: This was an analytic descriptive study done in Emergency Unit of Dr. Cipto Mangunkusumo Hospital from July to December 2014. We recruited all women who gave birth in Emergency Unit of Dr. Cipto Mangunkusumo Hospital from July to December 2014 with gestational age less than 37 weeks. Of the total sampling method, we got 365 patients. We analyzed the data using chi square.

Results: The characteristic age of subjects were $14.0 \%$ of less than 20 years old, $69.0 \%$ of $21-35$ years old, and the rest were more than 35 years old. Most subjects (93.1\%) were employed, 94.5\% were married once, $62.3 \%$ of subjects had cesarean section history, $73.7 \%$ were primiparous, only $4.4 \%$ had history more than 1 abortion, and most of them were at 33-36 weeks of gestation. Socio-demographic factor associated with preterm labor and Preterm Premature Rupture of Membrane (PPROM) was age ( $\mathrm{p}=0.011$; OR 1.74; $95 \%$ CI 1.136-2.679). Obstetric history associated with preterm labor and PPROM was parity ( $\mathrm{p}=0.017$; OR $1.78 ; 95 \%$ CI $1.132-2.878$ ).

Conclusion: In this study, age and parity are associated with preterm labor and PPROM.

[Indones J Obstet Gynecol 2017; 5-1: 3-7]

Keywords: obstetric history, parity, PPROM, preterm labor, socio-demographic factors
\end{abstract}

\begin{abstract}
Abstrak
Tujuan: Mengetahui faktor-faktor risiko yang mempengaruhi persalinan premature di RS Dr. Cipto Mangunkusumo.

Metode: Penelitian ini adalah studi deskriptif analitik yang dilakukan di IGD RS Dr. Cipto Mangunkusumo bulan Juli-Desember 2014. Populasi sampel penelitian ini adalah semua ibu yang melahirkan di IGD RSCM dengan usia kehamilan 20-36+6 minggu selama periode JuliDesember 2014 yang memenuhi kriteria inklusi dan eksklusi. Pengambilan sampel dilakukan dengan total sampling. Jumlah sampel yang terkumpul 365 sampel. Analisis data menggunakan chi square.

Hasil: Dari hasil penelitian didapatkan 14,0\% berusia kurang dari 20 tahun, 69,0\% berusia 21-35 tahun, dan sisanya berusia lebih dari 35 tahun. Kebanyakan subjek (93,1\%) bekerja; 94,5\% memiliki riwayat menikah sekali; 62,3\% memiliki riwayat sesar; 73,7\% hamil anak pertama; hanya 4,4\% yang perna h mengalami aborsi lebih dari 1 kali, dan sebagian besar dari mereka hamil usia kehamilan 33-36 minggu. Faktor sosiodemografi yang terkait dengan persalinan prematur dan ketuban pecah dini (KPD) prematur ialah usia $(p=0,011 ;$ OR 1,74; $95 \%$ IK 1,136-2,679). Faktor riwayat obstetri yang berhubungan persalinan prematur dan KPD prematur adalah paritas $(p=0,017 ;$ OR 1,78; 95\% IK 1,132-2,878).
\end{abstract}

Kesimpulan: Pada penelitian ini, usia dan paritas memiliki hubungan dengan persalinan prematur dan KPD prematur.

[Maj Obstet Ginekol Indones 2017; 5-1: 3-7]

Kata kunci: faktor sosiodemografi, KPD prematur, paritas, persalinan prematur, riwayat obstetri

\section{INTRODUCTION}

Neonatal mortality is a health problem in the world. One of the major causes of neonatal mortality is preterm labor. ${ }^{1}$ Preterm labor is a labor that occurs before 37 weeks of gestation. ${ }^{1}$ World Health Organization (WHO) reported that about 15 million preterm labors occurred annually and more than 1 million newborns died every year because of the preterm labor complication. ${ }^{1}$ Preterm newborn has certain health risks, such as cerebral palsy, intellectual impairment, chronic lung disease, and also vision and hearing impairment. The preterm labor does not only impact to the health condition of the newborn, but also to the family and environment.

Spontaneous preterm labor can be classified into preterm premature rupture of membrane (PPROM) and spontaneous labor without rupture of membrane. Spontaneous preterm labor can be caused by infection (intrauterine and extrauterine), twin pregnancy, placentae solution, hormonal imbalance, and idiopathic. Socio-demographic factors including maternal age, education, work, marital status and obstetric history, such as parity, antenatal care, complication during pregnancy influence the occurrence of preterm labor. ${ }^{1-3}$ 
If the risk factor has been determined earlier, we can do the early management to decrease the number of preterm labor. In the end, we can suppress the morbidity and mortality as a consequence of preterm labor. Looking to the burden of preterm labor, this study aims to determine the risk factors that affect preterm labor in Dr. Cipto Mangunkusumo Hospital.

\section{METHODS}

We used analytic descriptive study design to analyze the association between preterm labor and socio-demographic also obstetric factors in Emergency Unit of Dr. Cipto Mangunkusumo Hospital. The data was collected from medical records from July to December 2014. The subjects were collected using total sampling method. We got 365 subjects in this study. The subject population of this study was all women who gave birth in Emergency Unit Dr. Cipto Mangunkusumo Hospital with 20-36 weeks of gestation from July to December 2014 which were selected through using inclusion and exclusion criteria. The inclusion criteria of this study were pregnant women with 20-36 weeks of gestation and we excluded the intrauterine fetal death (IUFD) and women with medical complication. Sociodemographic factors analyzed in this study were age, work, and marital status. The obstetric history analyzed in this study included parity, abortion, antenatal care history, and low birth weight history. We analyzed using chi square in SPSS 21.0 version.

\section{RESULTS}

Table 1. Characteristics of Preterm Labor in Dr. Cipto Mangunkusumo Hospital

\begin{tabular}{|c|c|c|}
\hline Characteristics & n & $\%$ \\
\hline \multicolumn{3}{|l|}{ Age } \\
\hline$<20$ & 51 & 14.0 \\
\hline $21-35$ & 252 & 69.0 \\
\hline$>35$ & 62 & 17.0 \\
\hline \multicolumn{3}{|l|}{ Work } \\
\hline Employed & 337 & 93.1 \\
\hline Unemployed & 28 & 6.9 \\
\hline \multicolumn{3}{|l|}{ Marital Status } \\
\hline Married once & 345 & 94.5 \\
\hline Married more than once & 20 & 5.5 \\
\hline
\end{tabular}

\begin{tabular}{|c|c|c|}
\hline \multicolumn{3}{|l|}{ Labor method } \\
\hline Vaginal birth & 141 & 37.7 \\
\hline Caesarean section & 233 & 62.3 \\
\hline \multicolumn{3}{|l|}{ Parity } \\
\hline Primiparous & 269 & 73.7 \\
\hline Multiparous & 96 & 26.3 \\
\hline \multicolumn{3}{|l|}{ History of pregnancy } \\
\hline Primigravida & 157 & 43.0 \\
\hline Multigravida & 208 & 57.0 \\
\hline \multicolumn{3}{|l|}{ Abortion } \\
\hline $0-1$ & 349 & 95.6 \\
\hline$>1$ & 16 & 4.4 \\
\hline \multicolumn{3}{|l|}{ Weeks of pregnancy } \\
\hline 20-27 weeks & 13 & 3.5 \\
\hline 28-32 weeks & 100 & 26.7 \\
\hline 33-36+ weeks & 261 & 69.8 \\
\hline \multicolumn{3}{|l|}{ Antenatal care } \\
\hline Regular & 235 & 64.4 \\
\hline Irregular & 130 & 35.6 \\
\hline \multicolumn{3}{|l|}{ Low birth weight history } \\
\hline None & 337 & 90.1 \\
\hline $1-2$ & 35 & 9.3 \\
\hline$>2$ & 2 & 0.6 \\
\hline \multicolumn{3}{|l|}{ Preterm labor } \\
\hline PPROM & 171 & 46.8 \\
\hline Non PPROM & 194 & 53.2 \\
\hline
\end{tabular}

In this study, we collected 365 subjects among women who gave birth within 20-36 weeks of gestation. The characteristics of preterm labor were 51 women $(14.0 \%)$ whose age $<20$ years old, 252 women $(69.0 \%)$ whose age 21-35 years old, and 62 women $(17.0 \%)$ whose age $>35$ years old. The characteristic of occupation among subject population was 337 women (92.3\%) employed and the rest of 28 women (1.6\%) unemployed. The characteristic of marital status was 345 women $(94.5 \%)$ having married once and 20 women (5.5\%) marrying more than once. In our study, caesarean section (62.3\%) had been performed on preterm labor. Around $73.7 \%$ of women were primiparous and $57.0 \%$ were multigravida. The characteristic of abortion was on 349 women (95.6\%) having none or once history of abortion and 16 women (4.4\%) having more than once history of abortion. More than $50 \%$ of subjects had regular antenatal care. About 90.1\% women did not ever deliver low birth weight, 9.3\% delivered once to twice of low birth weight, and the rest had history more than twice. There were 171 women (46.8\%) having PPROM. 
Table 2. Association between Preterm Labor and Socio-demographic Factors

\begin{tabular}{|c|c|c|c|c|c|c|c|}
\hline \multirow{3}{*}{ Socio-demographic Factors } & \multicolumn{4}{|c|}{ Preterm Labor } & \multirow{3}{*}{$p$} & \multirow{3}{*}{$\mathbf{O R}$} & \multirow{3}{*}{$95 \%$ CI } \\
\hline & \multicolumn{2}{|c|}{ PPROM } & \multicolumn{2}{|c|}{ Non PPROM } & & & \\
\hline & $\mathbf{n}$ & $\%$ & $\mathbf{n}$ & $\%$ & & & \\
\hline \multicolumn{8}{|l|}{ Age } \\
\hline$<25$ & 75 & 43.9 & 60 & 30.9 & 0.011 & 1.74 & $1.136-2.679$ \\
\hline$>26$ & 96 & 56.1 & 134 & 69.1 & & & \\
\hline \multicolumn{8}{|l|}{ Work } \\
\hline Employed & 10 & 5.8 & 18 & 9.3 & 0.219 & 0.6 & $0.738-3.672$ \\
\hline Unemployed & 161 & 94.2 & 176 & 90.7 & & & \\
\hline \multicolumn{8}{|l|}{ Marital status } \\
\hline Married once & 163 & 95.3 & 182 & 93.8 & 0.536 & 1.34 & $0.536-3.368$ \\
\hline More than once & 8 & 4.7 & 12 & 6.2 & & & \\
\hline
\end{tabular}

Table 3. Association between Preterm Labor and Obstetric Histories

\begin{tabular}{|c|c|c|c|c|c|c|c|}
\hline \multirow{3}{*}{ Obstetric Histories } & \multicolumn{4}{|c|}{ Preterm Labor } & \multirow{3}{*}{$p$} & \multirow{3}{*}{ OR } & \multirow{3}{*}{$95 \%$ CI } \\
\hline & \multicolumn{2}{|c|}{ PPROM } & \multicolumn{2}{|c|}{ Non PPROM } & & & \\
\hline & $\mathbf{n}$ & $\%$ & $\mathbf{n}$ & $\%$ & & & \\
\hline \multicolumn{8}{|l|}{ Parity } \\
\hline Primiparous & 136 & 79.5 & 133 & 68.6 & 0.017 & 1.78 & $1.132-2.878$ \\
\hline Multiparous & 35 & 20.5 & 61 & 31.4 & & & \\
\hline \multicolumn{8}{|l|}{ Abortion status } \\
\hline $0-1$ & 164 & 95.9 & 186 & 95.4 & 0.808 & 1.14 & $0.415-3.129$ \\
\hline$>1$ & 7 & 4.1 & 9 & 4.6 & & & \\
\hline \multicolumn{8}{|l|}{ Antenatal care } \\
\hline Regular & 115 & 67.3 & 120 & 61.9 & 0.283 & 1.26 & $0.823-1.949$ \\
\hline Irregular & 56 & 32.7 & 74 & 38.1 & & & \\
\hline \multicolumn{8}{|l|}{ Low birth weight history } \\
\hline Yes & 14 & 8.2 & 22 & 11.3 & 0.313 & 1.43 & $0.709-2.900$ \\
\hline No & 157 & 91.8 & 172 & 88.7 & & & \\
\hline
\end{tabular}

Analysis using chi square showed that sociodemographic factor in preterm labor which was associated with PPROM was age $(\mathrm{p}=0.011$; $\mathrm{OR}=1.74$; 95\%CI 1.136-2.679). Meanwhile, obstetric history in preterm labor which had association with PPROM was parity $(\mathrm{p}=0.017$; $\mathrm{OR}=1.78$; 95\% CI 1.132-2.278).

Table 2 showed that 75 women (43.9\%) whose age $\leq 25$ years old had PPROM and 60 women $(30.9 \%)$ from the same age did not have PPROM. There were 96 women (56.1\%) whose age $>25$ years old having PPROM and 134 women (69.1\%) not having PPROM. Age was statistically associated with PPROM in preterm labor ( $\mathrm{p}=0.011$; $\mathrm{OR}=1.74$; $95 \%$ CI 1.136-2.679). Women whose age $\leq 25$ years old had the risk 1.74 times resulted into PPROM compared with women with more than 25 years old. In this study, women whose age $\leq 25$ years old had $63 \%$ probability to be PPROM. The other factors including occupation and marital status were not statistically associated with PPROM in preterm labor. 
Table 3 showed that parity was associated with PPROM in preterm labor. There were 136 primiparous women (79.5\%) having PPROM. In the group of multiparous women, there were 35 women $(20.5 \%)$ having PPROM and 61 women (31.4\%) not having PPROM ( $\mathrm{p}=0.017$; OR=1.78; 95\%CI 1.132-2.878). Primiparous women took 1.78 times risk to undergo PPROM compared with multiparous women in preterm labor. Therefore, primiparous women had $64 \%$ probability undergoing PPROM compared with multiparous women.

\section{DISCUSSION}

This study reported that preterm labor with PPROM occurred in $46.8 \%$ labor process; while, preterm labor without PPROM occurred in 53.2\% of the labor process in Dr. Cipto Mangunkusumo Hospital. Hammond, et al. reported that the prevalence of preterm labor with PPROM in Australia during 1984-2006 were 37\%; while, the prevalence of preterm labor without PPROM were $63 \% .^{2}$ Singh, et al. reported that the incidence of PPROM differed each country which was influenced by economic, environmental status, and antenatal care percentage. ${ }^{4}$ The most prevalent preterm labor in this study was found in women whose age between 21 to 35 years old (69.0\%). Savits, et al. reported that the most prevalent preterm labor was in the group of women whose age between 25 and 34 years old (39.4\%). ${ }^{5}$ Study conducted by Okeke, et al. showed that the most prevalent preterm labor with PPROM was found in women whose age ranging from 26 to 30 years old, which reached $43 \%{ }^{6}$ Sukhla, et al. showed that the most prevalent PPROM occurred in women whose age 21-25 years old (59\%). The reason of this condition was due to early marriage and too close spacing pregnancy. ${ }^{7}$

Most women involved in this study were unemployed (92.3\%) and had married only once (94.5\%). Caesarean section was the most prevalent labor method reported in this study (62.3\%). This report was contrasted to the study held by Noor, et al., which reported vaginal birth was the most prevalent labor method (66\%). It was affected by local tradition to be preferred for the homebirth. ${ }^{8}$ Primiparous women were the largest population having preterm labor in this study (73.7\%). Okeke, et al. also reported that preterm labor was found as the most prevalent in primiparous women. ${ }^{6}$
Preterm labor was found as the most prevalent in multigravida group (57\%) and in the group of women who had none or once history of abortion (95.6\%). Preterm labor mostly occurred during $33-36^{+6}$ weeks of gestation $(69.8 \%)$ and in women who had regular antenatal care (64.4\%). Most women involved in this study had no previous low birth weight history (90.1\%).

Age was statistically related to PPROM in preterm labor $(\mathrm{p}=0.011$; $\mathrm{OR}=1.74)$. This study also reported that women whose age $\leq 25$ years old had $63 \%$ probability having PPROM compared with women whose age $>25$ years old. Hammond, et al. reported that there was an increasing risk of preterm labor with PPROM in the group of women whose age $>35$ years old $(\mathrm{OR}=1.92 ; 95 \% \mathrm{CI}$ 1.76-2.08). Study in Sweden during 1973-2001 conducted by Morken, et al. reported that the older maternal age resulted in the higher risk of preterm labor. ${ }^{9}$ Nevertheless, this result was different from Savitz, et al. which reported that age was not associated with PPROM (95\% CI 0.9-1.4). ${ }^{5}$

Occupation and marital status were not associated with preterm labor. This result differed from study conducted by Hammond, et al., which stated that marital status was associated with PPROM (OR=1.41; 95\% CI 1.3-1.51). ${ }^{2}$ Zhang, et al. pointed out that among 1,391 women in Beijing, preterm labor was more frequent in the group of unmarried women. ${ }^{1}$

Parity was statistically associated with PPROM ( $\mathrm{p}=0.017 ; \mathrm{OR}=1.78 ; 95 \%$ CI 1.132-2.878). In this study, primiparous women raised the risk of 1.78 times to have PPROM compared with multiparous women. Noor, et al. in Pakistan reported that PPROM was found more often in multiparous women $(57.7 \%)$ than in primiparous women (42.3\%). Hammond, et al. stated that primiparous women were the risk factor of PPROM; while, multiparous women were the protective factor against PPROM (OR=0.48; 95\% CI 0.43-0.52). ${ }^{2}$ Henderson, et al. through their study in Australian Hospital during 2004-2008 declared that PPROM was found more prevalent in primiparous women $(50.4 \%)(p<0.001)$, especially in $34-36$ weeks of gestation. ${ }^{10}$ This result was different from Morken, et al. which reported that parity was not associated with PPROM in preterm labor (95\% CI 0.93-0.97). ${ }^{9}$ Another study conducted by Savitz, et al. declared that PPROM was found more prevalent in multiparous women $(\mathrm{OR}=1.1){ }^{5}$ 
In this study, abortion status and antenatal care were not associated with PPROM. Study in Beijing conducted by Zhang, et al. reported that antenatal care did not have association with preterm labor (OR=0.261; 95\% CI 0.134-0.510). This result was different from Aragao, et al. which reported that antenatal care was associated with preterm labor. ${ }^{11}$ The fact is that low socio-economic status has association with irregular antenatal care. Previous history of low birth weight was not associated with PPROM (OR=1.43; 95\% CI 0.7092.900).

\section{CONCLUSION}

Most of preterm labor reported in Dr. Cipto Mangunkusumo Hospital occurs without the rupture of membrane. Several factors related to preterm labor in this study are age and parity.

\section{REFERENCES}

1. Zhang YP, Liu XH, Gao SH, Wang JM, Gu YS, Zhang JY, et al. Risk factors for preterm birth in five Maternal and Child Health hospitals in Beijing. PloS one. 2012; 7(12): e52780.

2. Hammond G, Langridge A, Leonard H, Hagan R, Jacoby P, DeKlerk N, et al. Changes in risk factors for preterm birth in Western Australia 1984-2006. Int J Obstet Gynecol. 2013; 120(9): 1051-60.
3. Goldenberg RL, Culhane JF, Iams JD, Romero R. Epidemiology and causes of preterm birth. Lancet. 2008; 371(9606): 75-84.

4. Singh D, Usham R, Kamei H. Preterm prelabour rupture of membrane 1 year study. J Evol Medical Dental Science. 2015; 4(49): 8495-8.

5. Savitz DA, Harmon Q, Siega-Riz AM, Herring AH, Dole $\mathrm{N}$, Thorp JM Jr. Behavioral influences on preterm birth: integrated analysis of the pregnancy, infection, and nutrition study. Mat Child Health J. 2012; 16(6): 1151-63.

6. Okeke TC, Enwereji JO, Okoro OS, Adiri CO, Ezugwu EC, Agu PU. The Incidence and Management Outcome of Preterm Premature Rupture of Membranes (PPROM) in a Tertiary Hospital in Nigeria. Am J Clin Med Research. 2014; 2(1): 14-7.

7. Sukhla P, Bhargava M, Disha. Study of maternal and fetal outcome in preterm premature rupture of membrane. J Evol Med Dental Science. 2014; 3(7): 1789-95.

8. Noor S, Nazar AF, Bashir R, Sultana R. Prevalence of PPROM and its outcome. J Ayub Medical College. 2007; 19(4): 14-7.

9. Morken NH, Kallen K, Hagberg H, Jacobsson B. Preterm birth in Sweden 1973-2001: rate, subgroups, and effect of changing patterns in multiple births, maternal age, and smoking. Acta Obstet Gynecol Scandinavica. 2005; 84(6): 558-65.

10. Henderson JJ, McWilliam OA, Newnham JP, Pennell CE. Preterm birth aetiology 2004-2008. Maternal factors associated with three phenotypes: spontaneous preterm labour, preterm pre-labour rupture of membranes and medically indicated preterm birth. Int Society Perinatal Obstet. 2012; 25(6): 642-7.

11. Aragão VMdF, Silva AAMd, Aragão LFd, Barbieri MA, Bettiol $\mathrm{H}$, Coimbra LC, et al. Risk factors for preterm births in São Luís, Maranhão, Brazil. Cadernos de Saude Publica. 2004; 20: 57-63. 